\title{
14
}

\section{SELF-DETERMINATION THROUGH ADMINISTRATIVE REPRESENTATION \\ Insights from theory, practice and history}

\author{
Elizabeth Ganter
}

\section{Introduction}

In the period of Indigenous 'self-determination', Aboriginal and Torres Strait Islander representatives have moved between the public service and Indigenous organisations. In this chapter, I will draw on normative political theory to argue that such movements have contributed to selfdetermination in a way that was anticipated by a neglected source of advice on Indigenous administration and representation: the 1974-76 Royal Commission on Australian Government Administration ('the Royal Commission'), chaired by H. C. Coombs. ${ }^{1}$ The Royal Commission commenced one year after the Whitlam Government had announced a policy to 'restore to the Aboriginal people of Australia their lost power of self-determination in economic, social and political affairs' on 6 April 1973. ${ }^{2}$ Although the Royal Commission did not use the term 'selfdetermination', its recommendations on how to encourage Aboriginal participation in government, I will argue, canvassed the central issues that

\footnotetext{
Phillips, Politics of Presence; Mansbridge, 'Should Blacks Represent Blacks'; Dovi, 'Preferable Descriptive Representatives'; Dovi, The Good Representative.

2 Whitlam, 'Aborigines and Society'.
} 
have been raised by political theorists about 'descriptive representation'. That is, the Royal Commission's reflections on an unrepresentative public service and its 10 recommendations to address that problem were about how to constitute and then draw upon Indigenous voices to build the means of Indigenous self-determination.

The concept 'descriptive representation' is central to my argument. Political theorists use this term to refer to the possibility that political systems will be more democratic if minorities and politically marginal sections of society (such as women) are enabled to be visibly present in positions of power. Political parties, legislatures and bureaucracies enact descriptive representation when they ensure that a certain proportion of their personnel are members of constituencies (e.g. women, ethnic minorities and disabled people) that are considered to be (unjustifiably) marginal to, and lacking influence over, decisions that affect them. Those who have debated the worth of descriptive representation have argued that it is not sufficient for members of historically disadvantaged groups to be visibly present in positions of power. To gain strength and legitimacy in the processes of government, descriptive representatives need also to speak and act in ways that are accountable to their people - some have argued, through robust mutual relationships with members of the communities for which they speak.

Self-determination by Indigenous Australians needs descriptive representation. The normative political theory outlined above was implicit (and sometimes explicit) in the words of some Aboriginal and Torres Strait Islander senior public servants in the Northern Territory of Australia whom I interviewed in the period 2006-8. Unwilling to accede to the tokenistic 'any Indigenous person will do', some Aboriginal and Torres Strait Islander officials were applying stricter criteria to their representation of communities. Oscillating between jobs in the public service and in Indigenous organisations, they were searching for roles that both grounded them in their communities and empowered them in government decision-making. Their ambivalence about upward career mobility implied a standard by which they judged 'good' representation: maintaining community connection. Some found this standard hard to meet while they remained in government settings, though I do not mean to suggest that long-term Aboriginal and Torres Strait Islander public servants apply a different standard, as my research found them similarly motivated. I characterised Aboriginal and Torres Strait Islander officials 
as 'reluctant representatives' when their work neither connected them to their communities nor empowered them within the public service, but still made demands of their Indigeneity. ${ }^{3}$

\section{'Reluctant representatives'}

In interviews in the Northern Territory in 2007, I invited 76 Aboriginal and Torres Strait Islander senior public servants to reflect on whether they believed the Northern Territory Government's claim, in regularly published Indigenous employment statistics, that the Northern Territory Public Service was becoming an increasingly representative bureaucracy.

The interviewees described not only their family connections and their workplace experience, but also their motivations for entering and leaving the public service. The snowballing effect of my word-of-mouth recruitment had brought me into contact with nearly as many former employees as current employees, suggesting a high level of movement between the public service and Indigenous organisations. More than half the interviewees had worked in Indigenous sector organisations before becoming a public servant, or were still working in these organisations having left the public service. Of the 33 interviewees who were in senior government positions at the time of their interview, three years later, 10 or nearly one-third had moved into Indigenous servicing roles outside government, and one had already returned to government service. In response to these intriguing statistics, I observed that 'a professionally mobile group was in some kind of orbit between the public service and its publicly funded, arm's length organisations' ${ }^{4}$

To understand the significance of this mobility, we need to appreciate the relationship between the public service and the 'Indigenous sector' - 'the most important product of the policy era known as "self-determination". 5 The publicly funded Indigenous representative and service organisations are "neither the "state" ... [nor] "civil society" but a "third thing created out of the interaction ... of government and the Indigenous domain'. ${ }^{6}$ In 2011, anthropologist Patrick Sullivan argued that recent policy reform

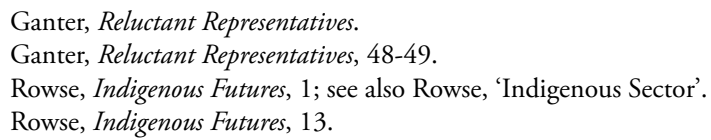


had glossed over important distinctions between this 'unacknowledged community sector' and other not-for-profit organisations. ${ }^{7}$ Indigenous organisations are like other not-for-profits in their reliance on public funding, but unlike other not-for-profits, Indigenous organisations incorporated under what was now the Corporations (Aboriginal and Torres Strait Islander) Act 2006 (or its state equivalents) are the institutional framework of Aboriginal civil society' and, for many communities, the main source of civic engagement, political identity and material security. ${ }^{8}$

Indigenous organisations are also like other not-for-profits in the larger sense of providing government 'at a distance. ${ }^{9}$ As I have noted elsewhere, they are 'government' in the sense that they are part of government's outsourced service delivery arm and comply with the government's terms of reference and rules of contracting. ${ }^{10}$ Indeed, a department and its funded providers may have more in common than that which divides them. One interviewee's career illustrated this well. After having been in the public service in a role servicing Indigenous communities earlier in his career, this interviewee had taken on a leadership position in an Indigenous representative organisation dealing with similar issues. He recalled having been actively recruited back into the public service to manage the government's side of an agreement he had helped set up while leading the organisation. This agreement required the government to match funding that had been granted to his former organisation with an in-kind contribution. This interviewee had agreed to the new public service role so he could follow up on the project from the inside or, as he put this to his recruiters, 'to know exactly what sort of in kind they were giving. ${ }^{11}$ At the time of his interview, he was again working for Aboriginal and Torres Strait Islander people from the outside; by the conclusion of the research, he was back in the government in a more senior role. He would later leave this position for an even more senior role as an external Indigenous representative spokesperson.

For this interviewee, as for others, the public service and the Indigenous sector were co-dependent and formed a combative relational space. Mobility within this space provided not only employment but also political identity. As I observed:

7 Sullivan, Belonging Together, 48-66.

8 Sullivan, Belonging Together, 50, 55-57.

9 Rose and Miller, 'Political Power', 180-81.

10 Ganter, 'Representatives in Orbit'; Ganter, Reluctant Representatives.

11 Ganter, Reluctant Representatives, 107. 
The interviewees did not describe a purely external political identity, but an orbital one in which Aboriginal and Torres Strait Islander participants were courted by both sectors as an asset in the government's engagement with [its] people. As long as Aboriginal and Torres Strait Islander participants were respectful of the concerns and priorities of their employers, they could move easily across sectors, and through this mobility forge an identity that was relatively autonomous of both. ${ }^{12}$

The public service was the employer of choice for many interviewees, as they found it better resourced and closer to decision-making. So why did some become frustrated and leave? If representation 'makes something present', descriptive representatives do this by the degree to which they resemble their group. In the same way, when Indigenous employment programs identified and selected Aboriginal and Torres Strait Islander public servants, they did so on the basis of their likeness to, or identity with, the 'under-represented' Indigenous population. Yet, Aboriginal and Torres Strait Islander public servants have been selected by the public service because they have skills and capacities other members of their group may not have. To participate in the public service was to accede to the construction of their people as the subjects of remedial policies and programs, which also distanced them from communities. Working in Indigenous organisations took Aboriginal and Torres Strait Islander officials closer to communities but further away from government decision-making. When in government, they clearly brought their identity to their work. But it was not this that distinguished them from other public servants: all public servants bring their identity into their work. It was their difference that made Aboriginal and Torres Strait Islander public servants distinct, or, in the words of political philosopher Charles Taylor, the fact that 'only the minority or suppressed cultures are being forced to take alien form'. ${ }^{13}$ That is, while the identity of public servants from majority populations was mostly unacknowledged, Indigenous employment programs marked Aboriginal and Torres Strait Islander recruits as different. Many interviewees commented that they felt singled out as Aboriginal and Torres Strait Islander public servants, perceived as representatives whether or not they sought that role or felt comfortable speaking for their communities. The interviews suggested that Aboriginal and Torres Strait Islander public servants saw the need to be more than

12 Ganter, Reluctant Representatives, 113.

13 Taylor, 'Politics of Recognition', 43. 
just statistics, or the passive representatives of their population; yet they were mindful of public service ethics, which made them unwilling to call themselves representatives in any other sense. 'Reluctant representatives' have no clear mandate to engage in the active representation of their people, yet they look to respond to invitations to speak up. ${ }^{14}$ To do otherwise is to begrudge their people a source of assistance. Not all interviewees had left the public service, but it was a possibility in the mind of all of them.

Indeed, to resist the formalistic, principal-agent view of representation, most interviewees were 'reluctant' to call themselves 'representatives' in any sense. They did not see themselves as acting on direct instruction from their constituency as a 'delegate', nor did their accounts suggest it. Their accounts more commonly suggested the 'trustee' relationship, bringing their own judgement to the role. When governments invite Aboriginal and Torres Strait Islander people into their bureaucracies, they are often not just seeking the passive, or descriptive, representation of their population, but their substantive judgements and advice as Indigenous people. To accept a job in Indigenous affairs, which my research showed is the most likely area in which a job will be available to an Aboriginal and Torres Strait Islander person, is to field calls on one's empathy, knowledge and connections - but represent who, how? ${ }^{15}$ What if a program is not working well in a community, and providing that advice appears subjective or rubs against unacknowledged public service norms? Public administration scholars long ago expressed doubts about how well administrative structures could reflect communities, arguing that the institutional norms of the public service would always prevail over the social identity of those recruited from under-represented sections of society, ${ }^{16}$ and some scholars have more recently observed that the link between passive and active representation had never been proven. ${ }^{17}$ In other words, minority personnel did not necessarily mediate between the government and the communities from which they were recruited.

A paradox of representative bureaucracy bedevils every public sector employment strategy that invites Aboriginal and Torres Strait Islander people to bring their Indigeneity to bear on Indigenous policies and programs. If identity is not important, why seek Indigenous contributions?

14 Ganter, Reluctant Representatives, 155.

15 Ganter, Reluctant Representatives, 59-70.

16 See, for example, Mosher, Democracy and the Public Service.

17 Meier and Hawes, 'Ethnic Conflict', 274. 
If identity is important, how can Aboriginal and Torres Strait Islander public servants be accountable to their communities and to government at the same time? To tease out these tensions, we need to look beyond the public administration account.

\section{'Good' representatives - developments in normative political theory}

When political theorist Hanna Pitkin in 1967 questioned the accountability of descriptive representatives who seek to act for their people, she initiated a prolonged and continuing defence of the descriptive representation of historically disadvantaged groups. ${ }^{18}$ Originally focusing on electoral representatives, scholars have gradually come to consider the role of informal descriptive representatives in a wider range of democratic contexts, including bureaucracies. ${ }^{19}$

Scholars have agreed that descriptive representation risks 'essentialising' that is, assuming that all members of the group have the same view of its interests. In the process of descriptive representation, divisions within the group are likely to become evident and may be exacerbated. Descriptive representation also creates the expectation that the point of view attributed to a group is unique to that group, forcing representatives to speak only for that bounded group, and leaving them 'isolated and marginalized at the representational level'. ${ }^{20}$ The interviewees' many stories about meeting invitations, corridor conversations and job interviews illustrated these problems. Yet, as political theorist Virginia Sapiro highlighted and my interviewees also theorised through their reflections, even if it is not easy to get right, descriptive representation is still necessary for the accountability of democratic government. ${ }^{21}$

The historical circumstances of the Northern Territory resemble the conditions that Jane Mansbridge has described as justifying descriptive representation: an extended history of distrust necessitating repairs to communication; the group's interests not 'crystallized' into a known

18 Pitkin, Concept of Representation.

19 For an excellent genealogy of the literature, see Suzanne Dovi, 'Political Representation', The Stanford Encyclopedia of Philosophy (Fall 2018 edition), edited by Edward N. Zalta, last updated 29 August 2018, accessed March 2019, plato.stanford.edu/archives/fall2018/entries/political-representation/.

20 Young, Inclusion and Democracy, 150.

21 Sapiro, 'When Are Interests Interesting'. 
agenda of reform; and the dominant group's 'fitness to rule' in question, so that the polity is seen to have a low level of legitimacy. ${ }^{22}$ Not all Australian Indigenous communities are in such circumstances, but it is common for Australian governments to underestimate Indigenous political capacities, despite the sophistication of some interlocutors. The Turnbull Government's rapid dismissal of Indigenous Australians' carefully prepared and executed 'Statement from the Heart' in 2017 is an illustration.

Among the models of descriptive representation that have emerged, Anne Phillips's 'politics of presence' comes the closest to justifying Indigenous public sector employment as a strategy for the descriptive representation of Aboriginal and Torres Strait Islander people in Australian bureaucracies. Phillips argues that it is better for minorities to be present in, than absent from, the corridors of power - even if, as she acknowledged, being in high places can seem elitist. The members of disadvantaged or dispossessed groups are likely to be better trustees of their group interests than individuals from more advantaged groups. As well, she argues, descriptive representatives provide role models, contribute 'overlooked' perspectives and increase democratic legitimacy. ${ }^{23}$ The interviewees mentioned these benefits, role modelling in particular. However, Phillips's theory does not explain other concerns of the interviewees: their exit rate and their wariness of substituting themselves for their absent people. Their accounts suggested that the 'politics of presence' sometimes worked against 'good' representation by making it easier for governments not to communicate directly with Aboriginal and Torres Strait Islander constituencies. ${ }^{24}$

By what standards should descriptive representatives be judged? Suzanne Dovi offered a single criterion: that 'preferable descriptive representatives possess strong mutual relationships with dispossessed subgroups of historically disadvantaged groups'. ${ }^{25}$ Dovi later argued the importance of this demanding criterion for any 'good representative', not just for descriptive representatives. ${ }^{26}$ Dovi's norm seems to go to the heart of the matter for the 'reluctant representatives' who spoke to me. They were reluctant to represent their people without authority or accountability;

22 Mansbridge, 'Should Blacks Represent Blacks', 644, 646, 649.

23 Phillips, Politics of Presence, 167-68.

24 Ganter, Reluctant Representatives, 97-103, 184-85; and see Young, Inclusion and Democracy, 123, 126-28.

25 Dovi, 'Preferable Descriptive Representatives', 729. Emphasis in original.

26 Dovi, Good Representative. 
yet, applying Mansbridge's conditions, their circumstances justified them trying. Political theory identifies the conditions under which descriptive representatives may substitute for the absent: when it would be remiss not to do so, because there would be a clear situational benefit to absent constituencies who in that particular instance could not possibly speak for themselves. ${ }^{27}$

Those interviewees who were in orbit between the public sector and Indigenous organisations were judging themselves more harshly; feeling that they were merely token was the most agonising of their concerns. What they really cared about was not their relationship with government, but how their communities would judge them. They wanted to sustain strong mutual relationships, to be recognised by disadvantaged members of their group as belonging to the same group and sharing the same aims or vision. Descriptive representatives ideally have 'a sense of sharing their fate with a historically disadvantaged group'. ${ }^{28}$ The 'good representative' must have this relationship with 'dispossessed subgroups' (Indigenous communities), who might otherwise be excluded twice - once by being a member of the historically disadvantaged group (Indigenous Australians), and a second time by the routine substitution of their own representative. It was in order to address this problem of connection and disconnection that many interviewees were moving between the public sector and Indigenous organisations. The careers of Aboriginal and Torres Strait Islander public servants who are seeking to influence the lives of their people are legitimately unsettled. The public sector positions them in places where they believe they can make a substantial difference to policies and programs, but where it is more difficult to have a robust interactive relationship with communities. The Indigenous sector positions them back with their dispossessed subgroup. Here they feel more grounded, but less empowered. Their mobility supplies the missing elements of each, and authenticates their efforts to be descriptive representatives with something to say. 


\section{The Royal Commission on Australian Government Administration}

In 1976, the Australian Government received good advice from the Royal Commission on Australian Government Administration. The Royal Commission's central task was 'to adapt the national public administration to the needs of contemporary government' through a 'fundamental rethinking of administrative principles and practices'. ${ }^{29}$ One of the Royal Commission's aims was to make the public service more representative of, and responsive to, sections of Australian society that had recently emerged as politically significant - for example, women, Indigenous Australians and non-English speaking migrants. The Royal Commission report was released under the Fraser Government in 1976. By then, 'self-determination' had been replaced by that government's preferred term 'self-management' for its policy approach in Indigenous affairs. Notwithstanding this change in language, the Fraser Government was in broad sympathy with the Whitlam Government's policy towards Indigenous Australians. Acknowledging 'the persistence of attitudes based on now rejected policies of assimilation and "protection", the Royal Commission endorsed 'respect for Aboriginal aspirations' as an objective of reformed government practice. ${ }^{30}$ The Royal Commission saw Aboriginal aspirations as twofold: to 'restore a distinctive Aboriginal culture' and to 'seek significant authority in the determination of policies and the management of programs concerned with their affairs'. ${ }^{31}$ The commissioners deliberated at length over how to respond so that Aboriginal people would be involved in both 'the processes of decision and ... the decisions themselves', that is, in both administration and policymaking. ${ }^{32}$

Ten recommendations of the Royal Commission, many of them multipart, touched on Aboriginal administration and representation, spread over two chapters of the report: ${ }^{33}$

29 Royal Commission on Australian Government Administration (Royal Commission), Report, 3.

30 Royal Commission, Report, 336.

31 Royal Commission, Report, 336.

32 Royal Commission, Report, 337.

33 In government writing, Torres Strait Islander people were not referenced as a separate people until the 1980 s. 
- In Chapter 8, 'Staffing the Administration - I Efficiency and Equity', under the heading 'equal opportunity and equity', Recommendation 136 (a-g) outlined 'a 5-10 year program of special recruitment and training. ${ }^{34}$

- In Chapter 10, 'Special problems of Administration', under the heading 'the administration of Aboriginal affairs', recommendations 289-97 covered external representation, the coordination of programs, processes for ministerial advice and the growth of Aboriginal institutions. ${ }^{35}$

The opening paragraphs of Chapter 8 outlined two concepts framing the Royal Commission's approach to Aboriginal and Torres Strait Islander participation in the public service: first, the government as an 'enlightened employer' and, second, 'government employment as a community instrument of policy'. ${ }^{36}$ The first concept encouraged the government to open the public service to diverse social categories, and the second suggested a broad channel of ideas between society and government. Without using the term, the two recommendations effectively proposed 'descriptive representation', which challenged conventional ideas of bureaucratic neutrality. Even though it is the basic premise of representative bureaucracy that people bring their identity into their work, the notion that this affects the judgements they make troubles the conventional presumption that executive government is the neutral instrument of policymaking, and that the legislature is policy's authoritative source. The Royal Commission did not see the bureaucracy as having been politically neutral: 'procedures for selection and the choice of the tests of merit' had introduced 'effective, if unintentional, discrimination against members of particular groups' ${ }^{37}$ The Royal Commission was clear in its warning that the under-representation of any significant citizen group in government employment 'must be regarded as prima facie evidence of discrimination or disadvantage or, at the very least, of a matter deserving investigation'. ${ }^{38}$ The report announced 'a bold and imaginative program of special recruitment, training and experience' towards the aim of achieving 'substantial Aboriginal participation in departmental work within a few years'.

\footnotetext{
34 Royal Commission, Report, 184-89.

35 Royal Commission, Report, 335-42.

36 Royal Commission, Report, 165-66.

37 Royal Commission, Report, 170-71.

38 Royal Commission, Report, 185.
} 
Recommendation 136 outlined 'a 5-10 year program of special recruitment and training of Aboriginals' - not only in the Department of Aboriginal Affairs (DAA), which had been established by the Whitlam Government in December 1972, but also in 'other departments with significant Aboriginal to total client ratios' as well as in 'the administration generally'. ${ }^{39}$ What was 'bold and imaginative' here? Recommendation 136 was a systematic effort to equip Aboriginal people to meet their own aspirations by respecting and supporting their social identity and community grounding. Recommendation 136 required that:

\begin{abstract}
Appropriately designed programs of general education, specialised training and graduated experience be developed to equip different categories of trainees to enter, at various levels, Commonwealth Government employment and Aboriginal incorporated organisations [emphasis added] (Recommendation 136d). ${ }^{40}$
\end{abstract}

The Royal Commission was here including Aboriginal organisations, the locally incorporated structures of self-determination for Aboriginal and Torres Strait Islander communities, in the proposed program of recruitment and training. By recommending further that 'formal educational programs required for this purpose be provided as far as possible by institutions outside the government service [emphasis added]' (Recommendation 136e), the Royal Commission sought to prevent the public service from monopolising training. ${ }^{41}$ Not only was the Royal Commission seeking to raise the number of Aboriginal public servants (to be at least population proportionate), it was trying to breathe fresh air into the public service by asking it to embrace Indigenous public sector employment as a 'community instrument'.

During the Royal Commission hearings, Aboriginal rights activist, Arrernte man and DAA Assistant Secretary Charles Perkins publicly questioned his public service seniors' commitment to his people's self-determination. Perkins had a wide public and media following, and must have provided the commissioners with a constant reminder of the risk of unrestrained internal representation by Aboriginal senior public servants. In $A$ Bastard Like $M e$, the autobiography Perkins published during the time of the Royal Commission, he warned government seniors that Aboriginal public

39 Royal Commission, Report, 188.

40 Royal Commission, Report, 188.

41 Royal Commission, Report, 188. 
servants were no longer their 'black messenger boys'. ${ }^{42}$ Did respecting Aboriginal aspirations mean accepting such challenges to public service authority? While Coombs was open to individual challenges to public service authority, his vision for Indigenous self-determination encouraged widely representative voices. Coombs heard Perkins as a witness to the Royal Commission, but he listened to other Aboriginal and Torres Strait Islander people and communities as well. Wisely, Recommendation 136 recognised that Aboriginal and Torres Strait Islander participation in government would grow both outside and inside government. The Royal Commission sought to support individual careers not only to improve government, but also to advance communities' self-determination.

Chapter 10's 'administration of Aboriginal affairs' recommendations (recommendations 289-97) took 'inside' administrative skills outside into Indigenous representative bodies and corporations. The first three recommendations (recommendations 289-91) focused on political expression, or building the skills and effectiveness of the Aboriginal elected body, the National Aboriginal Consultative Committee (NACC). ${ }^{43}$ The remaining recommendations (recommendations 291-97) followed four points of reform in the administration of Aboriginal affairs. The first point of reform faced inward. This recommendation asked the DAA to explore in centres with significant Aboriginal populations the feasibility of combining Aboriginal programs, while affirming continued responsibility by functional departments (Recommendation 292). Like the NACC recommendations, the remaining three points and associated recommendations faced outward. These were:

- To support the increasing participation, at the policy level, of representatively chosen Aboriginals': appoint a Ministerial Council comprising relevant department heads and NACC members, to be mirrored by regional and community committees reporting to the Ministerial Council half-yearly (Recommendation 293a-e), including on the evaluation of DAA programs (Recommendation 297) and informed by research on welfare indicators through collaboration between the DAA and the Australian Institute of Aboriginal Studies (as it was then known) (Recommendation 296).

42 Perkins, A Bastard Like Me, 172.

43 Royal Commission, Report, 337-38. 
- To support the 'growth of Aboriginal institutions': confirm the policy of 'steadily shifting responsibility for appropriate local and community tasks to Aboriginal institutions' (Recommendation 294) and conduct 'systematic study of the prerequisites of success for emerging institutions' through collaboration as above (Recommendation 295).

- To support the increasing participation of Aboriginals in administration and service delivery': implement Recommendation 136's 5-10 year recruitment and training program. Without this, the report explains, the recommendations for the administration of Aboriginal affairs would increase Aboriginal participation but would not meet the equal opportunity requirement. ${ }^{44}$

These recommendations sought to build Aboriginal capacity outside the public service because the commissioners did not view the Australian Public Service as constituted so as to listen to Aboriginal and Torres Strait Islander people. In taking this position, the commissioners may have been influenced by Charles Rowley, a consultant to the Royal Commission, who advised that Aboriginal policy input should come only from external representatives through a 'bargaining process' and not through Aboriginal public servants at all. ${ }^{45}$ This was consistent with Rowley's earlier argument that Aboriginal people needed a protective 'carapace' within which to build their own leadership and coalesce their political interests. ${ }^{46}$ Rowley was deeply sceptical of Aboriginal people's ability to participate in the bureaucracy without losing their identity, stating, "Aboriginality" has to be a significant qualification; this also must conflict with the Weberian values of the service in general'. ${ }^{47}$ Rowley was not opposed to recruiting Aboriginal public servants; he recommended a recruitment target of population-proportionate Aboriginal representation (1 per cent), across the entire public service. ${ }^{48}$ However, he had no faith that the channels of advice inside the government would serve them well, and he recommended replacing the DAA over time with a more representative 'Aboriginal Commission'. ${ }^{49}$

44 Royal Commission, Report, 339-42.

45 Royal Commission, Report, 361.

46 Rowley, The Remote Aborigines, 11.

47 Royal Commission, Report, 362.

48 Rowley, 'Aboriginals and the Administration', 363.

49 Rowley, 'Aboriginals and the Administration', 360. 
While the Royal Commission rejected Rowley's Aboriginal Commission and recruitment target, it adopted his other advice to build skill sharing, career mobility and external representation into the recommendations on the administration of Aboriginal affairs. Coombs must have hoped that narrow attitudes within the Australian Public Service would be challenged by more contact with Aboriginal public servants and organisations. Coombs's strategy for Indigenous political development was dual: providing for the sharing of 'inside' administrative skills with outside representative bodies, while at the same time bringing 'outside' personnel into the public service through employment and training.

It is possible to express this strategy in terms of the political theory outlined above: the Royal Commission saw descriptive representation through the inclusion of Aboriginal and Torres Strait Islander people as public servants as necessary but not sufficient for their inclusion in the democratic process. The Royal Commission appreciated the importance of Indigenous public sector employment, both for equal opportunity and to ensure that there was some Indigenous trusteeship of Indigenous policies and programs, but it also saw the risk of obliging Aboriginal and Torres Strait Islander public servants to serve political authorities other than the communities they were supposed to be representing. The Royal Commission's outward-facing recommendations for Aboriginal affairs administration - strengthen external representation, support Aboriginal institutions and mobilise Indigenous administrators - supported robust connections by building relationships between Indigenous administrators on the inside and their communities and organisations on the outside. Addressing both the internal and external dimensions of government, the Royal Commission's 10 recommendations on Aboriginal administration and representation urged the Australian Public Service to respond to a complex social and political circumstance. Aboriginal and Torres Strait Islander people had been promised self-determination, and the Royal Commission was empowering the public service by insisting that it reach out to Aboriginal and Torres Strait Islander communities.

\section{Concluding comments}

As a package, the recommendations of the Royal Commission on Australian Government Administration have been all but forgotten. While the Commonwealth, state and territory public sectors put considerable effort into employing Aboriginal and Torres Strait Islander public 
servants, they have been content with merely the passive representation afforded by such social diversity, and they have struggled to understand the job mobility of these recruits..$^{50}$ Experiments in building representative institutions external to the Australian Government have faltered. We have seen the demise of the NACC in 1977, the formation and dissolution of the National Aboriginal Conference (NAC, 1977-85) and the Aboriginal and Torres Strait Islander Commission (ATSIC, 1989-2005). There has been some investment in capacity building, including by training people to be functionaries in the many continuing Indigenous corporations, but this partial fulfilment of the Royal Commission recommendations has been offset by creating markets for public services in which Indigenous organisations must tender competitively for public money. The impact of this managerialism is still playing out in Indigenous affairs, where an Australian Public Service that has been hollowed out by decades of outsourcing has overlooked the importance of encouraging Aboriginal and Torres Strait Islander voices through external representation, and of keeping direct connections with service delivery.

Some Aboriginal and Torres Strait Islander people are participating in government by working beyond its conventional boundaries. They are operating in a more permeable, fluid and responsive zone of service delivery and representation than the public service, because their operational zone includes locally incorporated Indigenous organisations. They are drawing on public sector employment opportunities, taking their skills into the Indigenous sector and bringing their grounded knowledge and experience back into the public service. They are seeking robust mutual relationships that acknowledge that, as members of a people, they share fates with all Indigenous communities. Wherever they are positioned on the governmental spectrum, they are enriching the Indigenous polity. In these respects they are fulfilling the vision of the Royal Commission on Australian Government Administration. But they are doing this on their own initiative and at their own financial cost, not through good public policy, so the public service is not the meaningful player and instrument of Indigenous self-determination that it could be. If Indigenous career mobility is an indicator, many key players would prefer to speak through properly constituted representative voices than through the substitutive administrative voices that the public service currently encourages.

50 Biddle and Lahn, Understanding Decisions to Exit; Lahn, 'Being Indigenous'; Lahn and Ganter 'Representation, Recognition and Relationships'; see also Smith, 'Representative Bureacracy'. 
Aboriginal and Torres Strait Islander people's participation in the administration of Indigenous affairs is a matter of the utmost importance for their self-determining future and their right to be heard - but their participation in the public service will remain compromised while they have to leave it in order to speak and act in ways that meet their own standards of authenticity as representatives.

An opening observation of this chapter was that self-determination needs descriptive representation, and that both self-determination and descriptive representation need Indigenous Australians to be present in politically relevant and efficacious ways. Career mobility is building political efficacy for Indigenous representatives. They are crossing over the inside and outside dimensions of government to realise their ambitions and their people's ambitions. Through their movement between the public service and Indigenous organisations, they are presenting a model of Indigenous self-determination through administrative representation and applying performance criteria to themselves as descriptive representatives. Some Aboriginal and Torres Strait Islander people stay in the public service and try to improve its connection with external organisations. Some leave to work for similar agendas from the outside, where they often work in inadequately supported organisations. Of course, some never join the public service - but theirs would be a different story. Whatever their strategy of participation, when Aboriginal and Torres Strait Islander people are striving for an ethic of service and a standard of connection that involves mutual recognition with their disadvantaged communities, they are within reach of being 'good' representatives in political theory. And whatever else it needs, Indigenous self-determination must surely need good representatives.

\section{References}

Alcoff, Linda. 'The Problem of Speaking for Others'. In Who Can Speak?: Authority and Critical Identity, edited by J. Roof and R. Wiegman, 97-119. Urbana: University of Illinois Press, 1995.

Biddle, Nicholas and Julie Lahn. Understanding Aboriginal and Torres Strait Islander Employee Decisions to Exit the Australian Public Service. CAEPR Working Paper no. 110. Canberra: Centre for Aboriginal Economic Policy Research, The Australian National University, 2016.

Dovi, Suzanne. The Good Representative. Oxford: Blackwell Publishing, 2007. 
Dovi, Suzanne. 'Preferable Descriptive Representatives: Will Just Any Woman, Black, or Latino Do?' American Political Science Review 96, no. 4 (2002): 729-43. doi.org/10.1017/s0003055402000412.

Ganter, Elizabeth. 'Representatives in Orbit: Livelihood Options for Aboriginal People in the Government of the Australian Desert'. Rangeland Journal 33, no. 4 (2011): 85-93. doi.org/10.1071/rj11027.

Ganter, Elizabeth. Reluctant Representatives: Blackfella Bureaucrats Speak in Australia's North. Canberra: ANU Press, 2016. doi.org/10.1002/ajs4.32.

Lahn, Julie. 'Being Indigenous in the Bureaucracy: Narratives of Work and Exit'. International Indigenous Policy Journal 9, no. 1 (2018): 1-17. doi.org/ 10.18584/iipj.2018.9.1.3.

Lahn, Julie and Elizabeth Ganter. 'Aboriginal and Torres Strait Islander People in Public Service Roles: Representation, Recognition and Relationships in Australian Government Bureaucracies'. Special Issue on 'Aboriginal and Torres Strait Islander Employment: Key Issues for Policy, Practice and Research', Journal of Australian Political Economy 82 (2018): 133-48.

Mansbridge, Jane. 'Should Blacks Represent Blacks and Women Represent Women? A Contingent "Yes"'. Journal of Politics 6, no. 3 (1999): 628-57. doi.org/10.2307/2647821.

Meier, Kenneth J. and Daniel P. Hawes. 'Ethnic Conflict in France: A Case for Representative Bureaucracy?' American Review of Public Administration 39, no. 3 (2009): 269-85. doi.org/10.1177/0275074008317844.

Mosher, Frederick C. Democracy and the Public Service [1968]. New York: Oxford University Press, 1982.

Perkins, Charles. A Bastard Like Me. Sydney: Ure Smith, 1975.

Phillips, Anne. The Politics of Presence. Oxford: Clarendon Press, 1995.

Pitkin, Hanna F. The Concept of Representation. Berkeley: University of California Press, 1967.

Rose, Nikolas and Peter Miller. 'Political Power beyond the State: Problematics of Government'. British Journal of Sociology 43, no. 2 (1992): 173-205. doi.org/ $10.2307 / 591464$.

Rowley, Charles D. 'Aboriginals and the Administration: Royal Commission on Australian Government Administration', Appendix 3.1. Parliamentary Paper 188/1976. Canberra: The Government Printer of Australia, 1976. 
Rowley, Charles D. The Remote Aborigines: Aboriginal Policy and Practice. Volume 3. Canberra: Australian National University Press, 1971.

Rowse, Tim. Indigenous Futures: Choice and Development for Aboriginal and Islander Australia. Sydney: University of New South Wales Press, 2002.

Rowse, Tim. 'The Indigenous Sector'. In Culture, Economy and Governance in Aboriginal Australia, edited by D. J. Austin-Broos and G. Macdonald, 207-24. Sydney: Sydney University Press, 2005.

Royal Commission on Australian Government Administration. Report - Royal Commission on Australian Government Administration. Canberra: Australian Government Publishing Service, 1976.

Sapiro, Virginia. 'When Are Interests Interesting? The Problem of Political Representation of Women'. American Political Science Review 75, no. 3 (1981): 701-16. doi.org/10.2307/1960962.

Smith, Rodney. 'Representative Bureaucracy in Australia: A Post-colonial, Multicultural Society'. In Representative Bureaucracy in Action: Country Profiles from the Americas, Europe, Africa and Asia, edited by P. von Maravić, B. G. Peters and E. Schröter, 217-30. UK: Edward Elgar Publishing, 2013. doi.org/10.4337/9780857935991.00022.

Spivak, Gayatri. C. 'Can the Subaltern Speak?' In Marxism and the Interpretation of Culture, edited by C. Nelson and L. Grossberg, 271-313. Urbana: University of Illinois Press, 1988. doi.org/10.1007/978-3-658-13213-2_84.

Sullivan, Patrick. Belonging Together: Dealing with the Politics of Disenchantment in Australian Indigenous Affairs. Canberra: Aboriginal Studies Press, 2011.

Taylor, Charles. 'The Politics of Recognition'. In Multiculturalism and 'The Politics of Recognition': An Essay, edited by Amy Gutmann. Princeton, NJ: Princeton University Press, 1992.

Whitlam, E. Gough. 'Press Statement: Aborigines and Society, 6 April 1973'. Australian Government Digest 1, no. 2 (1973): 696-98.

Young, Iris M. Inclusion and Democracy. Oxford, UK: Oxford University Press, 2000 . 
This text is taken from Indigenous Self-Determination in Australia: Histories and Historiography, edited by Laura Rademaker and Tim Rowse, published 2020 by ANU Press, The Australian National University, Canberra, Australia.

doi.org/10.22459/ISA.2020.14 